\title{
"PEDAGOGY OF THE (LESS) OPPRESSED" A RESPONSE
}

John Anthony Scott Rutgers University

We too have read Paulo Freire's Pedagogy of the Oppressed, and have pondered the application of his analysis to the U.S. educational scene. We would be happy to join with the author of this article, and his friends, in setting up a discussion group upon this topic and in preparing materials that might form a basis for further discussion within the historical profession.

It is possible that Paulo Freire has much to teach us about the functions of "people's historians." Historians can help tear down the myths that distort or veil the meaning of our history; they can strive to identify, not with 'dominant elites,' but with the people themselves. They can rediscover, and renew their commitment to, dialogue as a central tool and technique of the process of teaching and of learning, of human and intellectual discovery.

These things, of course, are not new. But the study of Freire may help to emphasize them and to reinforce our consciousness of them in historical work.

The history teaching movement, this article claims, focuses upon ${ }^{r}$ methodology.' Improved 'methods,' the movement assumes, will solve the crisis in the classroom. But, we are now told, the problem lies rather with the students themselves: the kids are so turned off to the society in which they live that they have no motive to study it.

This comment indicates, to my mind, that the writer of "Pedagogy of the (Less) Oppressed" is perhaps not too familiar with what is happening in the history teaching movement. Our movement, at least in part, is a movement for a people's history. Teaching For A Change, for exaraple, was published in 1972 as a contribution to the theoretical underpinnings of the movement. Eighty per cent of its theme was a substantive not a methodological one--the substantive nature of people's history in the U.S.A. in the 1970s. Its entire refrain was that we must struggle to reach students by involving them in a history that is their own, that deals with people, not merely with 'ruling elites.'1

The central thrust of a movement for a people's history, as I understand it, is that we need to stress 'history from below.' This means, in the contemporary context of U.S. society, the story of the Native American peoples, of the Black people, the history of women, the struggle of working people and others for basic human rights. This, substantively, is a struggle for the humanization of our discipline.

My associates and I have experimented broadly with such teaching; and a number of us have embodied the experience gained from the classroom dialogue in historical writings. The Living History Library is, in its totality, a contribution to the writing of people's history that stems at one and the same time from historical ${ }_{2}$ research and from the work with students both in the
classroom and outside it.

The writer of "Pedagogy of the (Less) Oppressed," too, slights or ignores the work of many historians and teachers who have striven to make the living materials for a study of the people's past directly available to the present and future classroom generations. For example, the horizons for the teaching of Black history in this country have been revolutionized in the past twenty years by the work of historians, historical editors, and 
folklorists. To name only three among many, I would single out George Rawick's edition of the great Slave Narratives, John Blassingame's Slave Testimony, and Sue Eakin and Joseph Logsdon's edition of Solomon Northup's Twelve Years a Slave. I myself devoted two years to editing Frances A. Kemble's Journal of a Residence on a Georgia Plantation in 1838-9, and to reconstructing the Butler family's Altamaha River plantations. This work arose from classroom needs--the clearly articulated needs of women students to explore the life and oppression of 19 th century women and of Black women under slavery in particular.

The development of a style and philosophy of historical work that subordinates itself to the student, that studies his needs and seeks to respond to them, we have termed "the scholarship of teaching." Such a scholarship learns from the student and takes him as 1 ts gulde not only in the classroom but in the substantive research and writing that the historian undertakes. The scholarship of teaching, in our view, is to be distinguished from mandarin or elfte scholarship that too often is carried on in isolation from the real world and the needs of its people. Method, of course, has to be a part of scholarship, but only a subordinate part. In Teaching for a Change only three out of ten chapters were devoted to pedagogy; these dealt with the type of documents that we should be seeking for our students, with the use of historical drama and the stage, and with the artistic aspects of the teacher's vocation.

There are two further observations I would like to make about the article under consideration:

(a) Many U.S. teachers today are dissatisfied with educational life the way it is, are worried about the alienation of their students, are groping for new approaches to the classroom and to life. We hope that the writer of this article will not fall into the age-old trap of retreating into an ivory tower of 'advanced' theory. The very language that he uses-the terminology of Marx, Gramsci and Weber--may effectively isolate him from the people whom he should be trying to help.

(b) The writer, in putting down the history teaching movement for its alleged obsession with methodology, is belaboring a strawperson. The conflict between champions of 'method' and of people's history is a real one, but the writer presents one side of the movement as though it were the only side. It would be better for him and for us if he were to recognize that there is a conflict going on--and if he took sides.

Teaching in our country is not the same from year to year, certainly not from decade to decade. The mood of the country changes and the political climate changes too; such things affect the life and thinking of young people profoundly. In this situation, perhaps, our tactics may change but our strategy must endure. We must battle for history, in the classroom as out of it, as part of the battle for life. It is a weapon, after all, that offers giant flluminations; that equips human beings to grasp, with sober senses, the nature of the world they live in and to comprehend the destiny of human liberation which they are called upon to fight for and to fulfill.

\section{NOTES}

${ }^{1}$ John Anthony Scott, Teaching For 스 Change (New York, 1972).

${ }^{2}$ Living History Library (New York, 1967-1976), 15 volumes. The writing group for this venture consisted of Bill and Gene Bonyun, Steven Jantzen, Leondard Falkner, James McPherson, Douglas Miller, Martha Munzer, Milton Meltzer, John Anthony Scott, Laurence Seidman, and Marion Starkey. 
I recently presented a paper at a scholarly conference in which I attempted to sketch, very briefly, a theoretical model that might be valuable in understanding the relationships between class cultures, family cultures, and school cultures. The model was, I am now certain, a weak one, and the paper was not particularly inspired, but I trusted that at least my critics would attack the theory in such ways that I could deepen my own thinking, modify, strengthen or perhaps abandon the ideas, and, especially, contribute to the dialogue on that and related subjects.

My critics, instead, spent their alloted time chastising me for not writing a different paper, on the one hand, and for not minutely proving every hypothesis advanced, on the other--a task which would have made the paper into a monograph rather than a brief essay. None of them were willing to criticize the essay for what it was intended to be: a think-piece focusing on a few aspects of an obviously complex problem, with sharp limitations on its content dictated by the nature of the forum in which it was to be presented.

John Anthony Scott's response to my essay on history teaching leaves me as much without substantive comment as did my earlier critics. Rather than a critique of ideas and strictures, Scott prefers an ad hominem ("the writer. . Is perhaps not too familiar with what's happening. . ."). My failure to establish my credibility through a recitation of Scott's truly impressive work and writing has, apparently, made my observations invalid. To rectify my oversight, let me note that I have participated, with John Anthony Scott, on a panel on "History Teaching in the Secondary School," which was part of a conference on teaching history held at John Jay College in 1974; have long been a careful reader of the Newsletter produced by Scott and his associates; have benefitted from several re-readings of his Teaching for a Change; and have recommended that volume to countless teachers. Hence the carefully chosen words in the introductory paragraphs of my essay: "most, if not all, of the attention given the question of history pedagogy focuses on methodology." Certainly there are those in the movement who have given much thought to the questions I have sought to raise--the essay makes no pretense of uniqueness.

That said, however, I would urge even Scott and his colleagues to look again at the essay, for, in spite of their important efforts, the vast majority of material to appear in recent years on teaching history has ignored the subjective dimension suggested here. Indeed, it has been my experience that many who have reoriented their history content toward a people's history have ended with a content as antiquarian as any traditional history class. Radical antiquarianism seems only a little more capable of cutting through student alienation than the traditional variety. I am suggesting here that student alienation includes but extends well beyond the alienation from their own history.

On that ground, Scott's discomfort with theory is regrettable. For unless our dialogue has clear theoretical foundations, unless our classroom behavior springs from reasoned theoretical positions, we shall continue to generate irrelevant curricular and methodological reforms. Worse, we shall be in no position to critique the reforms as they appear, to sort out the positive from the merely irrelevant, and both from the positively harmful. There are enough of the latter on the horizon to make us all shudder.

The above notwithstanding, Scott's comments do provide a valuable elaboration of my argument that, in part, we must rethink content. I heartily endorse his brief bibliographical notes. Further, his closing paragraph deserves special note. It comprehends a view of history that should rededicate us each to our discipline and our teaching. 